\title{
The Effect of Psychodrama Group Therapy Applied to Mothers of Children with Type 1 Diabetes on the Role Skills, Adaptation Process, Quality of Life and Depression: A Mixed Methods Study
}

\author{
Çocuğu Tip 1 Diyabet Tanısı ile İlenen Annelere Uygulanan \\ Psikodrama Grup Terapisinin Rol Becerileri, Uyum Süreci, Yaşam \\ Kalitesi ve Depresyon Üzerine Etkisi: Bir Karma Yöntem Araştırması
}

\author{
Deniz KAYA MERAL ${ }^{\oplus}$, Ejder A. YILDIRIM $\odot$
}

\section{ABSTRACT}

Objective: This study aims to evaluate the effectiveness of the psychodrama group therapy on the quality of life and depression of mothers whose children have been diagnosed with T1DM, to retrieve a new relationship of mutually interactive roles in the relationship between mothers who have necessarily regressed to physiological roles with children who have been diagnosed with T1DM, and to raise the adaptive skills of mothers.

Method: Group study with mothers with children with type 1 diabetes consisted of 22 sessions. Fourteen individuals were included in the study: six in the therapy group and eight in the control group. The convergent parallel design, a mixed research method was used in the study. The quantitative data from the research were acquired using a "Personal Information Form", "Beck Depression Inventory Scale (BDI)", and "World Health Organization Quality of Life Scale Turkish Version (WHOQOL-BREF-TR)". The qualitative research data were collected using "Group Records Subjected to a Qualitative Content Analysis" and the "Social Atom Orbit Content" of participants acquired in the group application with Moreno's social atom orbit.

Results: In this study, a statistically significant decrease was found between pre-, and post-test BDI scores of the group members who participated in psychodrama sessions $(p<0.05)$. It was determined that WHOQOL-BREF-TR scale scores in the therapy group increased in the final test. In this study, the mother-child relationship was redefined by using psychodrama techniques. The formerly regressed relationship between mother and child has now been transformed to a new role relationship of mutual contact.

Conclusion: The results of our group study demonstrated that administering the psychodrama technique reduced the levels of depression in mothers with children diagnosed with T1DM, increased their quality of life scores, and was effective in harmonizing with the lives and other roles in life of the mothers.

Keywords: Type 1 diabetes mellitus, mothers, adaptation, depression, psychodrama

öz

Amaç: Yapılan bu çalışmada, T1DM tanılı çocuğu olan annelere uygulanan psikodrama grup terapisinin yaşam kalitesi ve depresyon üzerine etkinliğinin değerlendirilmesi, fizyolojik role zorunlu regrese olmuş anne ile T1DM tanılı çocuğu arasındaki ilişkinin birbirleriyle temas kurabilen yeni rol ilişkisine kavuşması ve annelerin uyum becerilerinin arttırılması amaçlanmıştır.

Yöntem: Tip 1 diyabetli çocuğu olan annelerle yapılan grup çalışması 22 oturum olarak gerçekleştirildi. Çalışmaya 6 terapi ve 8 kontrol grubu olmak üzere 14 kişi dahil edilmiştir. Araştırmada karma araştırma yöntemlerinden yakınsayan paralel desen kullanılmıştır. Araştırmanın nicel verileri, "Kişisel Bilgi Formu", "Beck Depresyon Ölçeği (BDÖ)" ve "Dünya Sağlık Örgütü Yaşam Kalitesi Ölçeği Kısa Formu Türkçe Versiyonu (WHOQOL-BREF-TR)" kullanılarak elde edilmiştir. Araştırmanın nitel verileri, "nitel içerik analizine tabi tutulan grup kayıtları" ve Moreno'nun sosyal atom yönergesi ile grup uygulamasında elde edilen katılımcıların "sosyal atom yörünge içerikleri" kullanılarak toplanmıștır.

Bulgular: Bu çalışmada, psikodrama uygulamasına katılan grup üyelerinin BDÖ ön test son test puanları arasında istatistiksel olarak anlamlı bir azalma görüldü ( $p<0.05)$. Terapi grubunda WHOQOL-BREF-TR ölçeği puanlarının son testte arttı̆̆ı belirlenmiştir. Çalışmada psikodrama tekniğiyle fizyolojik role zorunlu regrese olmuş anne çocuk ilişkisinden, birbirleriyle temas kurabilen yeni rol ilişkisine kavuşmaları sağlandı. Sonuç: Grup çalışmamızın sonuçları, psikodrama uygulamasının T1DM tanılı çocuğu olan annelerin depresyon düzeylerini azalttığını, yaşam kalitesi puanlarını arttırdığını, annelerin yaşamlarına ve yaşamdaki diğer rollerine uyum sağlamada etkili olduğunu göstermiştir.

Anahtar kelimeler: Tip 1 diabetes mellitus, anneler, uyum, depresyon, psikodrama

(c) Copyright Association of Publication of the Gaziosmanpaşa Training and Research Hospital.

This journal published by Logos Medical Publishing.

Licenced by Creative Commons Attribution 4.0 International (CC)

Received/Geliş: 16.03.2020

Accepted/Kabul: 10.07.2020

Published Online: 23.12.2020

Cite as: Kaya Meral D, Yildirim EA. The effect of psychodrama group therapy applied to mothers of children with type 1 diabetes on the role skills, adaptation process, quality of life and depression: A mixed methods study. Jaren. 2020;6(3):465-75.

Deniz Kaya Meral

Sağlık Bilimleri Üniversitesi, Gaziosmanpaşa Eğitim ve Araștirma Hastanesi,

İstanbul - Türkiye

denizkayameral@gmail.com ORCID: 0000-0002-7189-6022

E.A. Yıldırım 0000-0002-8620-1254 Sağlık Bilimleri Üniversitesi, istanbul Bakırköy Prof. Dr. Mazhar Osman Ruh Sağlığı ve Sinir Hastalıkları Eğitim ve Araștirma Hastanesi, Istanbul, Türkiye 


\section{INTRODUCTION}

Type 1 diabetes is an autoimmune disease characterized with the self-destruction of the beta cells that secrete insulin in the pancreas. In T1DM, called insulin- dependent diabetes mellitus or juvenile diabetes, the body produces very little or no insulin. Although the causes of this destructive state are not fully understood, genetic inclination, environmental triggers such as viral infections, toxins, or some nutritional factors are thought to instigate the autoimmune reaction ${ }^{(1-3)}$. Individuals with T1DM require insulin replacement to regulate the glucose levels in the body and they cannot survive without insulin $(3,4)$. T1DM is a chronic illness that is observed at all ages but it most frequently appears in children and adolescents ${ }^{(4)}$.

The number of children and adolescents under the age of 20 with T1DM around the world is estimated to be 1.110 .100 people ${ }^{(4)}$, and the number of diabetic children in Turkey is estimated to be $17.175^{(5)}$.

T1DM necessitates life-long management with daily finger-prick blood tests, insulin injections, and strict compliance with a diabetic diet. Blood sugar levels must be monitored, because hyperglycemia and hypoglycemia can be fatal. Poor compliance with the treatment regimen can lead to serious complications and, potentially, premature death ${ }^{(6)}$. Because young children have limited cognitive, behavioral, and socio-emotional capacities, they rely on their parents in daily T1DM care, which includes frequent blood sugar monitoring, insulin administering, and regulating diet and physical activity ${ }^{(7,8)}$.

Parents whose children are diagnosed with type 1 diabetes are observed to exhibit an initial grieving reaction similar to that which is fatal, generally up to 12 months after the diagnosis. During the diagnosis, they describe various emotions such as shock, denial, anxiety, sorrow, anger, guilt, shame, and frustration ${ }^{\left({ }^{9-12)}\right.}$. Additionally, fear of hypoglycemia, depression, anxiety, and sleep disorders can manifest. This situation continues until the age at which the child takes responsibility for the management of the disease ${ }^{(8,13,14)}$.

Children who have received a diagnosis of diabetes needs the support of their parents to ensure success in managing the disease ${ }^{(15)}$. Accordingly, imperatives that compel lifestyle changes in childhood closely concern the mothers primarily responsible for the care of their sick children as much as the children themselves. Since mothers establish greater empathy with their children, they experience relatively more stress and anxiety than other family members. The attention and awareness that disease management demands, while creating many challenges, precipitate confusion in their roles ${ }^{(15,16)}$.

Reviewing the concepts of sociometry regarding the roles will be beneficial in understanding mothers with children diagnosed with T1DM. A role is a task or behavior expected from an individual who occupies a certain position within a group. These roles include the roles of the mother, the child, and the nurse. Regarding the role of the mother, motherhood begins with the development of the infant in the mother's uterus. She meets the child's physiological needs such as feeding, changing diapers, sleeping and psychological needs such as love and attention. The mother is trusted, never abandons the child, and covers the needs necessary for the child's survival, ignoring her own needs ${ }^{(17)}$. It is one of the most challenging moments for a mother to learn that her child has such an illness, especially considering the role of the mother as described above. The mother regresses in her role relationship with the diagnosis of a disease. This regression exhibits itself as the mother's perception of her child as if in a phase of physiological need. The mother, feeling intense empathy with her child, starts life as if she herself is diabetic, and gains a new identity as "mother of a child with T1DM". This demands the process of reorganization compliance with the role relationship.

Moreno's sociometry, and especially psychodrama, relies on the role concept and theory. Moreno wanted to develop a treatment method through which people can express their thoughts and feelings in a state of action, setting out from the importance of motion in human life. The product of this effort is psychodrama. The word psychodrama means the transformation of a person's inner world to action. It thus becomes possible for members to display creative actions on the stage of psychodrama with 
increasing spontaneity and, through this means, ensure catharsis and gain insight. Psychodrama allows people to examine these conflicts they experience by animating them on the stage ${ }^{(18)}$.

Although there are descriptive studies in the literature review on coping and adaptation problems of families with children with T1DM, scarce number of studies have been conducted to solve these problems ${ }^{(9,11,16,19-22)}$. In the literature review, there are a limited number of studies examining the effect of psychodrama technique on the adaptation of parents to their new role relationship with the chronic disease of their children ${ }^{(23-26)}$. This study, conducted using psychodrama techniques, will ensure that mothers realize again and use more functionally the sources of their own identities and reestablish contact with life and people in a safe and supportive environment.

\section{AIM}

This study aims to evaluate the effectiveness of the psychodrama group therapy on the quality of life and depression of mothers whose children have been diagnosed with T1DM, to retrieve a new relationship of mutually interactive roles in the relationship between mothers who have necessarily regressed to physiological roles with children who have been diagnosed with T1DM, and to raise the adaptability of mothers.

\section{METHOD}

\section{The Type of the Research}

The research applied a mixed research method that included qualitative and quantitative data-collection and analysis process. The design classification of the research was a convergent parallel design. In this design type, the quantitative and qualitative data- collection process and analyses occur simultaneously or in proximate periods of time. The data integration process generally takes place after the analyses, generally conducted separately. The process regarding the research method was provided in Figure 1. In the research, non randomized pretest-posttest control group design, which is one of the quantitative research methods, and phenomenological method, which is one of the qualitative research approaches, were used.

\section{Study Population}

The group consist of the mothers with children who were referred to the pediatric endocrinology polyclinic at an education and research hospital on the Istanbul European side between the dates of October 2018 and February 2019. A brochure prepared for the study was distributed to parents referring to the polyclinic ( $N=22)$, but, because the employment of fathers prevented their participation in the study, interviews were conducted only with the mothers. Six individuals did not accept the invitation. The study was crafted as a result of preliminary interviews conducted with 16 individuals based on the principle of volunteer participation. The preliminary interviews were started two months before the study, because the number of patients referred to the polyclinic was limited, and participation in the group was allowed for six weeks. The study included fourteen individuals, including six in the therapy group and eight in the control group. Randomization was not performed, because the sample size was small.

Therapy group: Eight individuals said that they would be able to participate in the study in the preliminary interview, and the group began the first session with eight participants. The group began with eight individuals and concluded with six.

Control group: Eight volunteers who were unable to participate in the study in the preliminary interview were included in the control group. The BDI and WHOQOL-BREF-TR Scale were administered before the first and after the last session in the control group.

Group Processing: The participating group members collectively determined the application time for the study. Because each member dropped their children off at school or had to go to school at noon to deliver insulin or check blood sugar levels, the group sessions were held in the morning. The sessions were held two days in three units (a total of four hours and thirty minutes) a week, on Tuesdays and Thursdays, and a total of twenty-two sessions were conducted. The sessions were conducted on the terrace of the hospital. The group members were provided information about the volunteer principle, that psychodrama would be used as a method, that they would 
be supervised, and that the study would last twelve weeks. An explanation of the psychodrama method was provided in the preliminary interview.

\section{Data Collection and Analysis}

The quantitative data from the research were acquired using a "Personal Information Form", "BDI", and "WHOQOL-BREF-TR". SPSS for Windows 21 (Statistical Package for Social science for Windows, Version 21.0) package program was used in the analysis of quantitative data. Descriptive Analysis (arithmetic mean, standard deviation, minimummaximum, ratio, percentage) was used in evaluating the similarity of the therapy and control groups; Mann Whitney $U$ Test in comparison of therapy and control group pretest and posttest scale scores, and Wilcoxon Signed Ranks Test to compare the pretest and posttest scale scores of the experimental and control groups. The results were evaluated at a $95 \%$ confidence interval and $\mathrm{p}<0.05$ significance level. The data collection tools used were collected before the first session (personal information form and pretests) and after the last session (post tests) by the co-therapist in the therapy group. The data collection tools used were collected by the co-therapist in the control group at the first meeting (personal information form and pretests) and when the sessions of therapy group were completed (post tests).

Questionnaire Form: The questionnaire form was developed by researchers. Questions about the individual's background (such as age, marital status, education, job, economic status) which consisted of a total of 18 questions were included in survey forms (27-30).

Beck Depression Inventory (BDI): It is a 21-item scale developed by Beck et al. and adapted to Turkish by Hisli ${ }^{(31)}$. Each item in BDI aims to identify a behavioral pattern specific to depression. The items consist of a four-degree self-assessment sentence, which goes from less to more severe depression. Scores can be obtained from the scale in the range of 0 to 63 . The height of the total score indicates the severity of depression. Minimal (0-9 pts), mild (10-16 pts), moderate (17-29 pts), and severe (30-63 pts) degrees of depression were expressed with scores obtained as indicated. In Hisli's ${ }^{(31)}$ study, Cronbach alpha value was determined as $\alpha=0.80$.
World Health Organization Life Quality Scale Short Form Turkish Version (WHOQOL-BREF-TR): This scale developed by World Health Organization was adapted to Turkish by Eser et al. ${ }^{\left({ }^{22}\right)}$. This scale, which can be applied to non-elderly adults and consists of 26 questions, measures physical health, psychological health, social relationships, and environment well-being. Since each field expresses the quality of life in its field independently of each other, field scores are calculated between 4-20. As the score increases, the quality of life improves.

The qualitative research data were collected using "Group Records Subjected to a Qualitative Content Analysis" and the "Social Atom Orbit Content" of participants acquired in the group application using Moreno's ${ }^{(18)}$ social atom orbit.

Social Atom Application: The social atom is a measurable social reality which JL Moreno described in the sociometry theory, and frequently used in social structures. The "me" is at the nucleus of Moreno's social atom. The social atom is already the smallest indivisible social unit and is decided with the atom nucleus and orbit loads ${ }^{(18)}$. The measurement can be taken in the form of a social atom scale or directly, using and staging other group members within a group. The direct, onstage measurement was used because our study included group applications.

Group Records Qualitative Analysis: An assistant group leader recorded all group applications in writing. A researcher who did not participate in the group applications reevaluated these records in a content analysis. The researcher, in this evaluation, identified the themes and content used in the group sessions as blind for the order of applications. This analysis later identified the prominent themes in the initial, middle, and concluding sessions for the group, being redefined based on the order of group applications. Some applications, such as orbits regarding the perception and eating behaviors for sugar as a food, were used to facilitate this analysis in the sense of concrete data identifying how the groups processed and faced these.

Spectrogram Analysis: The spectrogram orbit was used in the analysis. In this orbit, two chairs were placed within the group circles, the first chair being 
paired with "emotions when you arrived" and the other with "what changed in yourselves, where are you going from here". Members were asked to perform their own process analyses. The spectrogram application, conducted in the form of group member staging regarding their initial and final emotions, was subjected to a content analysis defined as the final session.

\section{Ethics}

Gaziosmanpasa Taksim Education and Research Hospital Ethics Committee Permission dated November, 19, 2018 and numbered 91 was obtained from the Non-Interventional Clinical Research Ethics Committee. Written and verbal permission was obtained from the management of Gaziosmanpasa Taksim Education and Research Hospital. Members were informed before the study. In the preliminary interview, the members who verbally approved to participate in the study were asked to fill in the informed consent form by informing that they could leave the study at any time.

\section{Limitations}

The number of samples in the study is low and the findings of the current study may be limited to this population.

\section{RESULTS}

The individual characteristics of the group members participating in the study are shown in Table 1 . The mean age of the mothers participating in the therapy group was $37.67 \pm 4.546$ and the mean number of children was $1.67 \pm 0.567$. It was found that $83.3 \%$ of the mothers were from families with middle income level and $66.7 \%$ did not have T1DM in their family except their children. The average age of the mothers participating in the control group was $36.25 \pm 5.393$ and the average number of children was $2.00 \pm 1.035$.

Table 1. Individual Characteristics of Mothers of a Child with T1DM

\begin{tabular}{|c|c|c|c|c|c|}
\hline \multirow[b]{2}{*}{ Characteristic } & & \multirow[b]{2}{*}{$\begin{array}{c}\text { Therapy } \\
(n=6)\end{array}$} & \multirow[b]{2}{*}{$\begin{array}{c}\text { Control } \\
(n=8)\end{array}$} & \multicolumn{2}{|c|}{ Statistics } \\
\hline & & & & $\mathrm{Z}^{*}$ & $\mathbf{p}$ \\
\hline \multirow[t]{2}{*}{ Mother's Age (year) } & Min-Max (Median) & $33-45(37)$ & $25-44(36.50)$ & 0.000 & 1.000 \\
\hline & Mean $\pm S D$ & $37.67 \pm 4.546$ & $36.25 \pm 5.392$ & & \\
\hline \multirow[t]{2}{*}{ Number of Children } & Min-Max (Median) & $1-2(2)$ & $1-4(2)$ & -1.118 & 0.263 \\
\hline & Mean $\pm S D$ & $1.67 \pm 0.567$ & $2.00 \pm 1.035$ & & \\
\hline \multirow[t]{2}{*}{ Economic status $\mathrm{n}(\%)$} & Worse & $1(16.7)$ & $2(25.0)$ & -0.362 & 0.717 \\
\hline & Modarate & $5(83.3)$ & $6(75.0)$ & & \\
\hline \multirow[t]{2}{*}{ T1DM in Family; $\mathrm{n}(\%)$} & No & $4(66.7)$ & $6(75.0)$ & -0.329 & 0.742 \\
\hline & Yes & $2(33.3)$ & $2(25.0)$ & & \\
\hline
\end{tabular}

*Mann-Whitney U Test, ${ }^{*} p>0.005$

Table 2. Comparison of the Pretest-Posttest Scale Scores of the Therapy and Control Groups

\begin{tabular}{|c|c|c|c|c|c|}
\hline \multirow[b]{2}{*}{ Scales } & & \multirow[b]{2}{*}{$\begin{array}{c}\text { Pre test } \\
\text { Mean } \pm S D\end{array}$} & \multirow[b]{2}{*}{$\begin{array}{l}\text { Post test } \\
\text { Mean士SD }\end{array}$} & \multicolumn{2}{|c|}{ Statistics } \\
\hline & & & & $\mathrm{Z}^{*}$ & $\mathbf{p}$ \\
\hline \multirow[t]{2}{*}{ Beck Depression Inventory } & Terapy & $22.50 \pm 13.82$ & $12.50 \pm 7.31$ & -1.992 & 0.046 \\
\hline & Control & $18.13 \pm 9.047$ & $18.88 \pm 5.793$ & -0.634 & 0.526 \\
\hline \multirow[t]{2}{*}{ WHOQOL-BREF-TR (General Health) } & Terapy & $50.17 \pm 26.130$ & $56.33 \pm 15.188$ & -0.756 & 0.450 \\
\hline & Control & $42.25 \pm 20.048$ & $42.25 \pm 14.704$ & 0.000 & 1.000 \\
\hline \multirow[t]{2}{*}{ WHOQOL-BREF-TR (Physical Health) } & Terapy & $48.17 \pm 21.066$ & $50.50 \pm 20.993$ & -0.946 & 0.344 \\
\hline & Control & $60.25 \pm 17.203$ & $54.38 \pm 13.917$ & -1.703 & 0.089 \\
\hline \multirow[t]{2}{*}{ WHOQOL-BREF-TR (Psychological Health) } & Terapy & $51.00 \pm 28.369$ & $56.33 \pm 18.662$ & -0.210 & 0.833 \\
\hline & Control & $46.38 \pm 13.731$ & $47.38 \pm 11.019$ & -0.333 & 0.739 \\
\hline \multirow[t]{2}{*}{ WHOQOL-BREF-TR (Social Relationships) } & Terapy & $47.33 \pm 29.276$ & $55.50 \pm 19.675$ & -0.736 & 0.461 \\
\hline & Control & $55.13 \pm 19.082$ & $51.88 \pm 19.982$ & -1.342 & .0180 \\
\hline \multirow[t]{2}{*}{ WHOQOL-BREF-TR (Environment) } & Terapy & $48.50 \pm 21.031$ & $53.17 \pm 9.745$ & -0.531 & 0.595 \\
\hline & Control & $57.50 \pm 13.949$ & $53.00 \pm 11.723$ & -1.687 & 0.092 \\
\hline
\end{tabular}

*Wilcoxon Işaretli Sıralar Testi, **p $>0.05$ 
It has been found that $75.0 \%$ of them had middle income and $75.0 \%$ of them had not T1DM in their family except their children. All members participating in the study showed similar characteristics in terms of individual characteristics ( $p>0.005$ ).

Comparison of the pretest-posttest scale scores of the therapy and control groups are given in Table 2 . The pre-test scores of the therapy, and control groups were $22.50 \pm 13.82$ and $18.13 \pm 9.047$, respectively, and it was found that the mothers experienced moderate depression. A statistically significant difference was found between Beck Depression Inventory pretest-posttest scores of the group members who participated in the study $(Z=-1.992 ; p<0.05)$. While the Beck Depression Inventory scores of the therapy group decreased in the post-test, but the scale scores of the control group did not change.

There was no statistically significant difference between the General Health Status, Physical Health, Psychological, Social Relations and Environment pretest post-test scores, which are the subparameters of the Quality of Life Scale of the group members participating in the study $(\mathrm{Z}=-0,756 ;-0,946 ;-0,210$; $-0,736 ;-0,531 \quad p>0.05)$. There was no statistically significant difference between the General Health Status, Physical Health, Psychological, Social Relations and Environment pre-test posttest scores, which are the subparameters of the Quality of Life Scale of the control group members $(Z=0,000 ;-1,703 ;-0,333$;

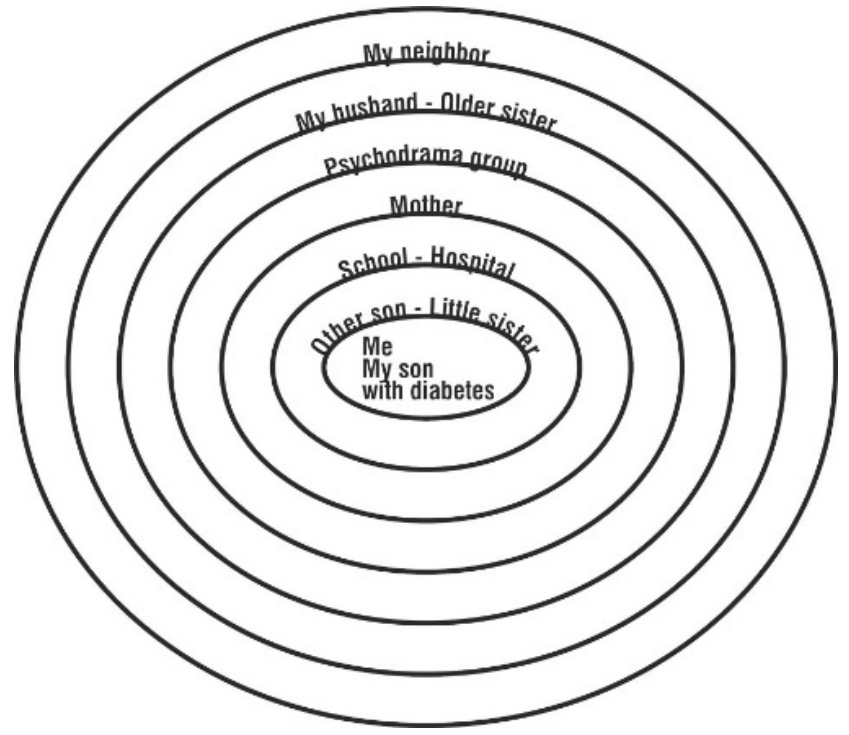

Figure 2. Social Atom of Member 3 in Session $7^{\text {th }}$ and $\mathbf{2 0}^{\text {th }}$
$-1,342 ;-1,687 p>0.05)$. However, while the Therapy Group's Quality of Life Scale scores increased in the post-test, the scale scores of the control group did not change or decreased. Mothering of a Child With Type 1 Diabetes.

\section{Group Qualitative Analysis:}

The prominent themes in the initial sessions were intense dejection because a child received the diagnosis of diabetes, lamenting being unable to mother a healthy child, intense anxiety, inability to separate from the child, loneliness, and helplessness. In the

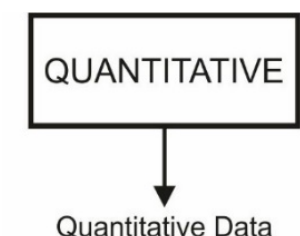

- Questionnaire Form

- Beck Depression Scale

- World Health Organization Life Quality Scale Short Form Turkish Version

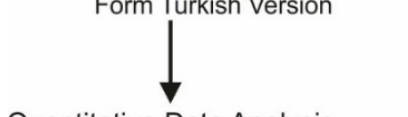

Quantitative Data Analysis

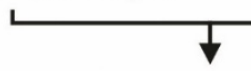

Qualitative Data Analysis

Compare Emerging Findings

Qualitative Data

- Group Records Qualitative Analysis

- Moreno's Social Atom Directive

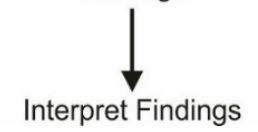

Figure 1. Convergent Parallel Design

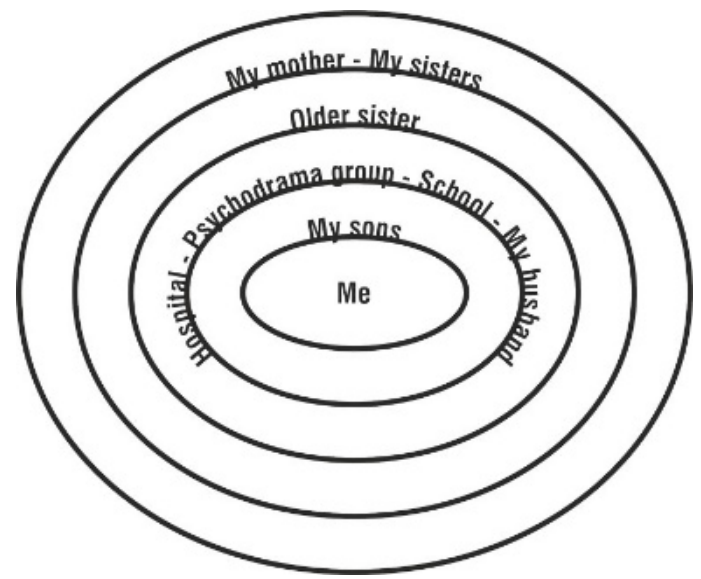


middle sessions, however, partner conflicts, expectations with "me" language, demands, tears, and emotional catharsis emerged. Future sessions saw an increase in statements with "me" language, constructing the future with "me" language, reduced guilt while discussing their children, and pleasant moments with children (Picture 1).

\section{Social Atom Application:}

In the seventh session, in the social atom game we chose to evaluate the social relationships of members with the assistant leader, the members were at the nucleus with their diabetic children. Each mother here views herself with her children as a single collective and preserves the relationship as such. We decided to play social atom again to decouple this. The children were in the orbit with the social atom task held during the 20th session (Figure 2).

\section{Spectrogram Analysis:}

Table 3 provides the themes and emotions of group members at the initial-ending stages. The themes and emotions during the initial stage generally appeared as "my child, fear, helplessness, diabetes, loneliness, unhappiness, and being lost". Members expressed the themes and emotions during the ending stage as "me, my, happiness, sharing, independence, support, strength, courage, and trust".

Table 3. Themes and Emotions of Group Members at the InitialEnding Stages

\begin{tabular}{|c|c|c|}
\hline Members & $\begin{array}{c}\text { Initail Themes and } \\
\text { Emotions }\end{array}$ & $\begin{array}{c}\text { Ending Themes and } \\
\text { Emotions }\end{array}$ \\
\hline Member 1 & $\begin{array}{c}\text { My child } \\
\text { Fear } \\
\text { Helplessness }\end{array}$ & $\begin{array}{c}\text { Me } \\
\text { my ... (possesive) } \\
\text { Happiness }\end{array}$ \\
\hline Member 2 & $\begin{array}{l}\text { My child } \\
\text { Diabetes }\end{array}$ & $\begin{array}{c}\text { Sharing } \\
\text { Independence } \\
\text { Me }\end{array}$ \\
\hline Member 3 & $\begin{array}{c}\text { Diabetes } \\
\text { Loneliness }\end{array}$ & $\begin{array}{c}\text { Me } \\
\text { Support }\end{array}$ \\
\hline Member 4 & $\begin{array}{l}\text { Unhappiness } \\
\text { Helplessness }\end{array}$ & $\begin{array}{l}\text { Strength } \\
\text { Me } \\
\text { Courage }\end{array}$ \\
\hline Member 5 & Being lost & $\begin{array}{l}\text { Trust } \\
\text { Strength } \\
\text { Me }\end{array}$ \\
\hline Member 6 & $\begin{array}{l}\text { Loneliness } \\
\text { Helplessness }\end{array}$ & $\begin{array}{l}\text { Sharing } \\
\text { Me }\end{array}$ \\
\hline
\end{tabular}

\section{DISCUSSION}

This study aims to evaluate the effectiveness of the psychodrama group therapy on the quality of life and depression of mothers whose children have been diagnosed with T1DM, to retrieve a new relationship of mutually interactive roles in the relationship between mothers who have necessarily regressed to physiological roles with children diagnosed with T1DM, and to raise the adaptability of mothers. The BDI scores administered to the members who participated in the psychodrama sessions have fallen significantly compared to the prior application. No change occurred in the control group. Depression in parents with a child with type 1 diabetes is the most common and most dangerous comorbidity seen when the child or family cannot manage diabetes due to repeated hospitalizations and $\mathrm{HbA} 1 \mathrm{c}$ levels are decreased ${ }^{(7)}$. The depression caused by this life-threatening disease on parents is more severe in mothers compared to fathers ${ }^{(33)}$. In a systematic review, Barnard et al. ${ }^{(34)}$ reported that the fear of hypoglycaemia, anxiety, and depression are common in parents. In a study with mothers whose children have T1DM, $27.7 \%$ of mothers reported having mental health problems ${ }^{(10)}$. According to the Beck Depression Scale pretest scores of our study, it was found that the mothers in the therapy and control groups had moderate levels of depression according to the Beck Depression Scale pre-test scores. In the literature, there is no study on the effect of psychodrama on depression in mothers whose children have T1DM, but there are studies on mothers who have children with chronic disease. In their research study, Kivraklar and Celik ${ }^{(24,26)}$ reported that psychodrama provided a significant decrease in the depression levels in mothers with autistic children. In Guler's ${ }^{(23)}$ study, psychodrama was reported to be effective in reducing depression in mothers with mentally retarded children. These results show that our study is similar to the literature. In our study, the average scores for the WHOQOL-BREF-TR administered to the members who participated in the psychodrama sessions increased compared to the prior application. No change occurred in the control group. There are descriptive studies on the quality of life of parents with children with T1DM $(12,35,36)$ but no study was found regarding the direct effects of psychodrama on the quality of life of par- 
ents with children diagnosed with T1DM. Unal ${ }^{(25)}$ reported that psychodrama has a positive effect on increasing life satisfaction of mothers with children with disabilities. In addition, we can also evaluate the effect of our study on the scale results through spectrogram analysis. The themes and emotions during the initial stage generally appeared as "my child, fear, helplessness, diabetes, loneliness, unhappiness, and being lost". When group members repaired their feelings of helplessness with psychodrama, the guild and inadequacy they experienced decreased. Thus, the Quality of Life Scale score averages increased, while the Beck's Depression Inventory Scale scores decreased.

The three-stage application goals were identified with the supervisor before the group began. These were creating group cohesion for the initial session, inverting the concept of "Mother Me" gradually to "Me Mother" with protagonist games for the middle process sessions, and "Me and I am a mother" for the final session. We had members play warm-up and protagonist games in line with these goals.

The first notable aspect of the group introduction during the ice-breaker games played during the first sessions was that, while introducing themselves, the most frequently used word was "diabetes", and everything was defined through diabetes. The central point of all this was diabetes. Everyone there knew that everyone else was the mother of a diabetic child but introduced themselves saying, "While introducing 'me' as a subject, I am a diabetes subject". This demonstrates that the mother, feeling intense empathy with her child, begins to life as if she herself is diabetic, and gains a new identity as "mother of a child with T1DM". Winnicott specifies that there is a primary relationship between mothers and children and defines mothers as a mirror that reflects what their children see ${ }^{(37)}$. This information supports our findings. Any study cited in the literature has examined the influence of the psychodrama technique on the harmony of parents with the new role relationship they acquire with the disease. However, Bektas (38) conducted a study that reviewed the effect of psychodrama in the harmonization of families with T1DM.

The members in the group, as they realized their own stories and pain, were able to situate and harmonize with their own pasts and today's pain in one place. With the protagonist games, they were able to become more creative, because they again dealt with the imperative of "me", with which they previously struggled with. Another study conducted on mothers with children diagnosed with T1DM emphasized the importance of identifying resources that can reduce the burden of stress and obligation mothers feel after the diagnosis of diabetes is made and can provide support ${ }^{(19)}$. Yalom ${ }^{(39)}$ said that groups occupy a paramount position in meeting the psychological, sociological, and physiological needs of people such as learning more quickly, changing behaviors and attitudes, gaining valid behaviors, and acquiring information about how to act in certain situations met through groups; and indicated that the skill of coping with problems is gained through groups. Our findings in the study demonstrated that the group itself had the strength of improvement. Along with gaining a sense of belonging to the group and no longer feeling alone, with the group being self-improving, the members passed from a state of "mother of a diabetic" to a state of "I am a mother". The group met all the goals by the end, and the group emerged as "me and I am a mother".

The initial determination of the study was that the role function between the mother and child regressed to the period of the child's birth. To assess the social relationships of the members, the members were at the nucleus with their diabetic children in the social atom game selected during the seventh session. Each mother here views herself with her children as a single collective and preserves her relationship as such. According to Winnicott, the mother-child relationship is dynamic, vibrant, and interactive and is a broader, more focused empathetic conception than merely meeting biological needs. This conception must be satisfying, creative, and entertaining in skillfully ensuring the development of a healthy, animated personality ${ }^{(37)}$. Self-psychology representatives stress that empathetic interactions are paramount in the healthy psychological development of individuals. Heinz Kohut believes that the empathetic response of parents is substantial in the development of a healthy personality ${ }^{(40)}$. In general, parental empathy has a positive impact in a child's process of socialization and in their development of 
appropriate behaviors ${ }^{(37)}$. In line with this information, it was salient for the ability of children to develop that mothers were emancipated from this situation. The mother and child are now an integrated whole, because there was something further that connected her child to her "diabetes!" and from which they could not distance themselves. When we consider this as nuclei and orbits in Moreno's social atom, if the mother is at the center, the child cannot live in the orbit ${ }^{(18)}$. The mother returned to the role of physiological needs, experiencing regression in her relationship with her child. Her child is no longer in his or her own world, no longer with his or her own role capacity but instead a child reborn in the stage of physiological needs. This child cannot live without a mother. From the moment a mother who has returned to the physiological role enters a relationship with her child, then this mother no longer comprises a single component, and the child has entered the mother's own identity. This emphasizes the importance of demonstrating to mothers that there exists a whole other world, of increasing their capacity to form relationships, and, while doing this, of coming to terms with the world they have created, with the helplessness of the person in the face of diabetes. When improving the regression of these women, roles other than physiological ones can be taken by the children. With the social atom study repeated in the 20th session, the children were not anymore in the orbit. In a study, Bektas ${ }^{(38)}$ looked at the effect of psychodrama in adapting families to T1DM, the contribution of psychodrama to families' developing positive relationships with their children was also mentioned. This finding is similar to our study.

In the final group sessions, these women were anymore able to see and meet their own and each other's needs. The friendship they needed in their social lives arose in the group. The group met all the goals by the end, and the group emerged as "me and I am a mother". They celebrated this birth by applying henna.

\section{CONCLUSION}

The "mother-me" personality perception that emerges due to an intense symbiotic relationship created with a child acknowledged as being incapable of independence or living alone again transforms into a "me-mother" perception. The relationship between a mother and her child that has, out of necessity, regressed to the physiological role gains a new role in which the child and, actually, the mother are accepted as independent social individuals. The members' repairing parts of themselves with the helplessness they felt reduced the guilt and incompetence they experienced, and this increased their harmony with the new role relationships that began with the disease. The child in the nucleus in the social atom passed to the orbit. These mothers, who experienced social isolation with the unwillingness and loneliness they felt regarding inability to set aside time for themselves, described themselves as freer at the end of the study. The blame ignited at the end of the session symbolized the birth of "me" and that they had become able to reapply their spontaneity and creativity. The fact that members of the group, no longer able to even add sugar when making pudding, brought homemade foods in the final goodbye session demonstrated that they had benefitted from the psychodrama.

\section{Suggestions}

One of the most important reasons that the number of members was low in this study was that the mothers had no place to leave their children. For this reason, we could recommend two psychodramatic studies in which rehabilitation can be simultaneously provided for the children and mothers unable to bring their children. While conducting this study, twenty-two sessions were administered to see the trajectory and which games worked better. As a result of the observations, 12-16 sessions of planning could be recommended for future studies. In the diabetes training outpatient clinics, information on the management of type 1 diabetes and education about the disease are provided, but psychosocial support is also needed in such a difficult process. This study emphasizes the importance of consultation liaison psychiatry nursing which is one of the health disciplines in providing this support to patients and families. In addition, more frequent use of this method by consultation liaison psychiatry nursing is recommended.

\section{Funding Statement}

During this study, no financial or spiritual support 
was received either from any pharmaceutical company that has a direct connection with the research subject or from a company that provides or produces medical instruments and materials which may negatively affect the evaluation process of this study.

Ethics Committee Approval: T.C. Ministry of Health Health Directorate Taksim Training and Research Hospital Clinical Research Ethics Committee approval was obtained (19.09.2018/91).

Conflict of Interest: No conflict of interest has been declared by the authors.

Funding: During this study, no financial or spiritual support was received either from any pharmaceutical company that has a direct connection with the research subject or from a company that provides or produces medical instruments and materials which may negatively affect the evaluation process of this study.

Informed Consent: Receipt.

\section{REFERENCES}

1. Atkinson MA, Eisenbarth GS, Michels AW. Type 1 diabetes. Lancet. 2014;383(9911):69-82. [CrossRef]

2. Chellappan DK, Sivam NS, Teoh KX, Leong WP, Fui TZ, Chooi K, et al. Gene therapy and type 1 diabetes mellitus. Biomed Pharmacother. 2018;108:1188-200. [CrossRef]

3. Weber DR, Jospe N. Diabetes Mellitus. In: Kliegman RM, Stanton BMD, Geme JS, Schor NF, editors. Nelson Textbook of Pediatrics. 21 ed: Elsevier Inc.; 2019. p. 3019-52.

4. Federation ID. IDF Diabetes Atlas BEXCO, Busan, Korea 2019 [9 $9^{\text {th }}$ edn. :[Available from: http://www.diabetesatlas.org.

5. Yesilkaya E, Cinaz P, Andiran N, Bideci A, Hatun S, Sari $E$, et al. First report on the nationwide incidence and prevalence of Type 1 diabetes among children in Turkey. Diabet Med. 2017;34(3):405-10. [CrossRef]

6. Ellis M, Jayarajah C. Adolescents' view and experiences of living with type 1 diabetes. Nurs Child Young People. 2016;28(6):28-34. [CrossRef]

7. L Z, T L. Supporting parents of children with type 1 diabetes mellitus: a literature review. Patient Intelligence. 2015;7:21-31. [CrossRef]

8. Pierce JS, Aroian K, Caldwell C, Ross JL, Lee JM, Schifano $E$, et al. The ups and downs of parenting young children with type 1 diabetes: A crowdsourcing study. J Pediatr Psychol. 2017;42(8):846-60. [CrossRef]

9. Bowes S, Lowes L, Warner J, Gregory JW. Chronic sorrow in parents of children with type 1 diabetes. J Adv Nurs. 2009;65(5):992-1000. [CrossRef]

10. Talakoub S, Nasiri M. Affective responses of the parents after diagnosis of type 1 diabetes in children. Iran J Nurs Midwifery Res. 2012;17(2 Suppl 1):S96-s100.
11. Whittemore $R$, Jaser $S$, Chao A, Jang $M$, Grey $M$. Psychological experience of parents of children with type 1 diabetes: a systematic mixed-studies review. Diabetes Educ. 2012;38(4):562-79. [CrossRef]

12. Johnson LN. Parent Distress in Life with a Child with Type 1 Diabetes [Graduate Theses and Dissertations]. Florida: University of South Florida; 2013.

13. Lindstrom C, Aman J, Norberg AL. Parental burnout in relation to sociodemographic, psychosocial and personality factors as well as disease duration and glycaemic control in children with Type 1 diabetes mellitus. Acta Paediatr. 2011;100(7):1011-7. [CrossRef]

14. Limbers CA, Teasdale A. Parenting Stress in Fathers of Children With Type 1 Diabetes. Fam Community Health. 2018;41(2):117-22. [CrossRef]

15. Lindstrom C, Aman J, Norberg AL, Forssberg M, Anderzen-Carlsson A. "Mission Impossible"; the Mothering of a Child With Type 1 Diabetes - From the Perspective of Mothers Experiencing Burnout. J Pediatr Nurs. 2017;36:149-56. [CrossRef]

16. Khandan MPC, Abazari FP, Tirgari BP, Cheraghi MAP. Lived experiences of mothers with diabetic children from the transfer of caring role. Int J Community Based Nurs Midwifery. 2018;6(1):76-88.

17. Akhtar S. The mother and her child: clinical aspects of attachment, separation, and loss. 2012.

18. Dokmen U. Sociometry and Psychodrama. Istanbul: Remzi; 2013.

19. S. Sullivan-Bolyai JD, Gruppuso P, Tamborlane W, Grey $M$. Constant vigilance: Mothers' work parenting young children with Type 1 diabetes. Journal of Pediatric Nursing. 2003;18(1):21-9. [CrossRef]

20. Wennick A, Lundqvist A, Hallström I. Everyday experience of families three years after diagnosis of type 1 diabetes in children: a research paper. Journal of Pediatric Nursing. 2009;24(3):222-30. [CrossRef]

21. Acar AE. Effects of chronic diseases on family functions and life satisfactions of the patients [master thesis]. Izmir: Dokuz Eylul University; 2011.

22. Susan Sullivan-Bolyai MG, Janet Deatrick, Philip Gruppuso, Pamela Giraitis, William Tamborlane. Helping Other Mothers Effectively Work At Raising Young Children With Type 1 Diabetes. The Diabetes Educator. 2004;30(3):476-84. [CrossRef]

23. Guler N. Psychodrama study in moms with mentally handicapped children [Psychodrama Thesis]. Istanbul: Abdulkadir Ozbek Psychodrama Institute; 2007.

24. Kivraklar D. Psychodrama with mothers of children with autism [Psychodrama thesis]. Izmir: Abdulkadir Ozbek Psychodrama Institute; 2013.

25. Unal TK. Psychodrama with disabled child mothers [Psychodrama thesis]. Izmir: Abdulkadir Ozbek Psychodrama Institute; 2015.

26. Celik Y. Supporting mothers with authistic children with the psychodrama method [Psychodrama thesis]. Ankara: Abdulkadir Ozbek Psychodrama Institute; 2017.

27. Secgin D. The difficulties of care about children faced by families with the children suffering from type 1 diabetes [Master]. Istanbul: Marmara University; 2006.

28. Boztepe H. Determination of problems experienced by mothers of adolescents having type 1 diabetes and evaluation of efficacy of improved nursing approaches [Doctorate]. Ankara: Hacettepe University 2010. 
29. Ustun S. Comparison of adaptation period and adjustment level to disease, in juvenile diabetic children and in their families [Master]. Izmir: Dokuz Eylul University 2011.

30. Sahin G. The effect of diet quality on metabolic control and nutritional status of adolescents with type 1 diabetes [Master]. Ankara: Ankara University; 2018.

31. Hisli N. A Study on the validity of beck depression inventory. Psychology Journal. 1989;6:118-22.

32. Eser E, Fidnner H, Fidaner C, Eser SY, Elbi H, Göker E. Psychometric properties of WHOQOL-100 and WHOQOL-BREF. 3P Journal. 1999;7:23-40.

33. Saghaei M, Omidi P, Dehkordi EH, Safavi P. The effectiveness of cognitive-function stress management training in glycemic control in children and in mental health of mother caring for child with type 1 diabetes mellitus. Diabetes Metab Syndr. 2017;11 Suppl 2:S925s8. [CrossRef]

34. Barnard K, Thomas S, Royle P, Noyes K, Waugh N. Fear of hypoglycaemia in parents of young children with type 1 diabetes: a systematic review. BMC Pediatr.

\section{0;10:50. [CrossRef]}

35. Faulkner MS, Clark FS. Quality of life for parents of children and adolescents with type 1 diabetes. Diabetes Educ. 1998;24(6):721-7. [CrossRef]

36. Herbert LJ, Clary L, Owen V, Monaghan M, Alvarez V, Streisand R. Relations among school/daycare functioning, fear of hypoglycaemia and quality of life in parents of young children with type 1 diabetes. J Clin Nurs. 2015;24(9-10):1199-209. [CrossRef]

37. Simonič B. Empathic parenting and child development. The Person and the Challenges. 2015;5(2):109-21. [CrossRef]

38. Bektas B. Psychodrama: helping families to adapt to childhood diabetes. Therapeutic Approach. 2006;3:14953. [CrossRef]

39. Yalom ID. Theory and Practice of Group Psychotherapies. Istanbul: Kabalci; 2015.

40. Clark AJ. Self Psychology and Emphaty. Empathy in Counseling and Psychotherapy: Perspectives and Practices. New Jersey: Lawrence Erlbaum Associates; 2015. p. 125-9. [CrossRef] 